\title{
A multi-proxy approach reveals common and species-specific features associated with tree defoliation in broadleaved species
}

\author{
E. Gottardini ${ }^{\mathrm{a}, *, 1}$, F. Cristofolini ${ }^{\mathrm{a}}$, A. Cristofori ${ }^{\mathrm{a}}$, M. Pollastrini ${ }^{\mathrm{b}}$, F. Camin ${ }^{\mathrm{a}, \mathrm{c}}$, M. Ferretti $^{\mathrm{d}}$ \\ ${ }^{\mathrm{a}}$ Research and Innovation Centre, Fondazione Edmund Mach (FEM), Italy \\ ${ }^{\mathrm{b}}$ University of Firenze, Department of Agriculture, Food, Environment and Forestry, Firenze, Italy \\ ${ }^{\mathrm{c}}$ Center Agriculture Food Environment (C3A), University of Trento, Italy \\ ${ }^{\mathrm{d}}$ Swiss Federal Research Institute WSL, Birmensdorf, Switzerland
}

A R T I C L E IN F O

\section{Keywords:}

Forest monitoring

Tree health

Tree crown condition

Defoliation

Functional leaf traits

\begin{abstract}
A B S T R A C T
Tree crown defoliation is the most widespread indicator of forest health and vitality in Europe. It is part of the ICP Forests Pan-European survey and it is adopted for reporting under Forest Europe. It is readily understandable and can count on fairly harmonized, long-term, large-scale data series across Europe. On the other hand, it is unspecific with respect to possible causes of damage, and its relation with tree functioning remains unclear. This study focused on European beech (Fagus sylvatica L.), Turkey oak (Quercus cerris L.), and holm oak (Quercus ilex L.), three important broadleaved forest species in southern Europe. We investigated whether and to what extent morpho-physiological (functional) leaf traits and other indicators of foliar, branch and stem health condition are associated with tree defoliation. We tested the relationship between defoliation and leaf-, branch- and stem attributes, and whether indicators of damage and functional leaf traits significantly differ (Mann-Whitney U Test) between defoliated (defoliation $>25 \%$ ) and undefoliated trees (defoliation $\leq 25 \%$ ). For each species, we considered one site (three to five plots each) and $n=11-19$ randomly selected trees. For each tree, the following indicators were measured: crown condition (defoliation; leaf-, branch- and stem damage, in terms of extent and intensity of damage), leaf morphology (leaf thickness, leaf area, lamina length, fluctuating asymmetry, specific leaf area, damaged leaf surface), leaf physiology and chemistry (chlorophyll $a$ fluorescence, chlorophyll content, carbon and nitrogen stable isotopes composition $\delta^{13} \mathrm{C}, \delta^{15} \mathrm{~N}$, carbon/nitrogen ratio). Results show that, for the selected trees of all the three species, defoliation was positively related to the extent of damage on branches. While increasing defoliation in European beech was also accompanied by several significant differences at leaf level (i.e., leaf damage, leaf volume, dry weight, carbon/nitrogen ratio and photosynthetic efficiency), for Turkey oak and holm oak the significant differences between defoliated and undefoliated trees were limited to damage on branches (both species).
\end{abstract}

\section{Introduction}

Forests are subjected to a variety of biotic (e.g. pests, diseases) and abiotic (e.g. climate and extreme weather events, fire, direct damage due to management operations, air pollutants) stress factors that can have a serious impact on forest health and vitality (e.g. Gea-Izquierdo et al., 2019; Vacek et al., 2015). Healthy forests are an important target for sustainable forest management (SFM) (FOREST EUROPE, 2015). Proper monitoring is therefore essential to document their conditions, to investigate the effects of - and relationship with - stress factors (Ferretti and Fischer, 2013), as well as to estimate their ability and potential to provide environmental, economic and social benefits. The visual estimation of tree crown defoliation (a popular term used to identify the reduction of foliage on tree crowns) is currently used among the suite of indicators to report forest health and vitality in Europe (FOREST EUROPE, 2015). Defoliation, defined as the loss of foliage in relation to a reference standard (Eichhorn et al., 2016), has been adopted since the 1980s on different spatial scales, from the continental one (e.g. ICP Forests monitoring network, active in Europe since 1980s; http://icp-forests.net), to the national (e.g. Innes, 1991) and sub-national scales (e.g. Bussotti et al., 1995; Pollastrini et al., 2016; Bussotti et al., 1992; Gottardini et al., 2016). Although defoliation can be influenced by several factors and its assessment can be affected by the observer bias (e.g. Innes, 1998; Seidling, 2019), data on

\footnotetext{
* Corresponding author. Tel.: + 390461 615362; fax: + 390461650956.

E-mail address: elena.gottardini@fmach.it (E. Gottardini).

${ }^{1}$ ResearcherID: G-8483-201.
} 
this indicator remain unique to obtain large-scale, long-term information on tree condition (e.g. Ferretti et al., 2014; Iacopetti et al., 2019; Potočić et al., 2018). Defoliation is a rather unspecific indicator (Ferretti, 1997, 1998) and - although evidence of its relationship with tree growth reduction exists (e.g. Solberg, 1999; Solberg and Tveite, 2000) - very few insights are available on possible links between the severity of defoliation and the functional characteristics of trees (Gottardini et al., 2016; Pollastrini et al., 2016). For these reasons, it has been proposed to combine defoliation assessment with the measurement of other (field-assessed) indicators able to provide more specific and functionally-oriented information on trees (Bussotti and Pollastrini, 2017; Pollastrini et al., 2016).

In this study a multi-proxy approach was adopted, complementing the evaluation of tree crown defoliation with damage symptoms occurring at foliar, branch and stem level, as well as with morphological and eco-physiological traits at leaf level. We targeted trees from three out of the most widespread broadleaved forest species in Italy: Fagus sylvatica L. (European beech), Quercus cerris L. (Turkey oak), and Quercus ilex L. (holm oak) (IFNC, 2007). The European beech is frequently the dominant tree in broadleaved stands of central and Eastern Europe over different pedological substrates (Brumme and , 2009), avoiding very acidic conditions. In Italy European beech forests cover over one million hectares (IFNC, 2007). Turkey oak extends from southern Europe to Asia Minor (De Rigo et al., 2016) and covers around 880,000 ha in Italy (IFNC, 2007); holm oak is native to the centralwestern Mediterranean basin, where it represents the dominating species in woodlands and maquis vegetation (De Rigo and Caudullo, 2016) and covers about 620,000 ha in Italy (IFNC 2007). We conducted field observations of visual indicators of tree condition (defoliation and damage) and complemented such observations with measurements of functional leaf traits (i.e. "hands-on" foliar symptoms, leaf morphology, carbon and nitrogen isotopes, chlorophyll content, chlorophyll $a$ fluorescence). We aimed to test whether:

(i) Leaf traits and other indicators are associated with defoliation and are thus able to point out a potential eco-physiological dysfunctionality of trees;

(ii) The defoliation $>25 \%$ (i.e., the traditional threshold to distinguish between "healthy" and "damaged" trees (Lorenz et al., 2001)) is reflected by distinct change also in functional leaf traits and other indicators of tree health.

\section{Materials and methods}

\subsection{Study design}

Measurements were carried out in Tuscany (central Italy) at three sites (one per species) (Fig. 1) and on a total of $n=12$ plots (three to five per site and species), with an area of $800 \mathrm{~m}^{2}$ each. Plots were randomly located within a larger area $\left(800-5000 \mathrm{~m}^{2}\right)$, subjected to the same forest management, and organized in a $15 \times 35 \mathrm{~m}^{2}$ core area $\left(525 \mathrm{~m}^{2}\right)$ surrounded by a $2.5 \mathrm{~m}$-wide buffer zone $\left(275 \mathrm{~m}^{2}\right.$ ) (Ferretti et al., 2016b). We considered a total of $n=44$ dominant (Kraft's classes $1,2)$ trees: European beech $(n=19)$, Turkey oak $(n=14)$ and holm oak $(n=11)$ (Table 1$)$. The measuring campaign took place during the 2016 growing season, between June and September, and crown condition and leaf traits were evaluated simultaneously on each plot within each site.

\subsection{Tree condition assessment}

Crown defoliation and leaf, branch and stem damages were assessed on all dominant (Kraft's classes 1,2) trees with a diameter at breast height $(\mathrm{DBH}) \geq 10 \mathrm{~cm}$ in the core area, and $\mathrm{DBH} \geq 40 \mathrm{~cm}$ all across the plot. Defoliation was assessed in $5 \%$ steps by trained and experienced personnel. Both absolute (Ferretti, 1994; Mueller and Stierlin, 1990) and relative (local reference tree) reference standards were adopted
(Eichhorn et al., 2016). For the visual assessment of damage, the affected tree compartment (i.e. leaves, branches, stem), the main categories of causal agents (i.e. game and grazing, insects, fungi, abiotic agents, direct action of man, fire, atmospheric pollutants, other factors, investigated but unidentified) and the extent of the damage (in 5\% classes referring to the portion of affected leaves, branches or stem) were considered (Eichhorn et al., 2016). The total number of damaging agents and the number of affected parts recorded for each tree were calculated from these data.

\subsection{Leaf sampling and leaf traits measurement}

Three trees per plot were randomly selected for leaf traits measurements, one from each of the following defoliation classes: no defoliation, $\leq 10 \%$; slight defoliation, $>10-25 \%$; moderate to severe defoliation, $>25 \%$. In addition, the tree with the highest defoliation value in each plot was purposely selected, when not occurring as a result of the random sampling. Tree climbers collected a branch from each tree, from a randomly selected azimuthal direction of the upper light-exposed portion of the crown, cutting a length of its distal part in respect to the stem of about one meter. The sampled branches were stored in cool bags for $3-6 \mathrm{~h}$, until their processing. In order to carry out laboratory measurements, all leaves, including the petiole, were removed from each branch and pooled in one sample per tree. The following subsamples were randomly selected for each tree:

(i) $\mathrm{n}=78-100$ leaves for the visual assessment of the damaged surface (see 2.3.1);

(ii) $\mathrm{n}=15$ leaves for physiological (i.e., chlorophyll $a$ fluorescence and chlorophyll content; see 2.3.2) and morphological measurements (see 2.3.3);

(iii) $\mathrm{n}=100$ leaves for dry weight and isotope contents (see 2.3.3 and 2.3.4).

\subsubsection{Damaged leaf surface (DLS)}

On average, the damage extent was visually assessed on 87 leaves (min 78; max 100) per tree and classified in three classes according to the percentage of damaged leaf area: scarcely damaged: $\leq 10 \%$ (DLS < 10); medium damaged: $>10-50 \%$ (DLS 10-50); highly damaged: $>50 \%$ (DLS > 50).

\subsubsection{Chlorophyll a fluorescence and chlorophyll content}

The chlorophyll $a$ fluorescence was measured by means of the Handy-PEA (Hansatech Instruments, Pentney, Norfolk, UK) portable fluorimeter on 15 dark-adapted $(20 \mathrm{~min}$ ) leaves per plant. The rising fluorescence transients, from the minimal $F_{0}$ to the maximal $F_{M}$ fluorescence intensity, were induced by a red light emitted from an array of three ultra-bright red LEDs (peak wavelength $650 \mathrm{~nm}$ ) and recorded for $1 \mathrm{~s}$, starting $50 \mu \mathrm{s}$ after the onset of illumination. The fluorescence data, plotted on a logarithmic time scale, show a polyphasic curve: the different steps are labelled as $\mathrm{O}\left(=\mathrm{F}_{0}, 50 \mu \mathrm{s}\right), \mathrm{J}(2 \mathrm{~ms}) ; \mathrm{I}(30 \mathrm{~ms})$ and $\mathrm{P}$ (peak $=\mathrm{F}_{\mathrm{M}}$, the highest fluorescence intensity). The variables considered in this study are (Strasser et al. 2000):

(i) $\mathrm{F}_{\mathrm{V}} / \mathrm{F}_{\mathrm{M}}=\left(\mathrm{F}_{\mathrm{M}}-\mathrm{F}_{0}\right) / \mathrm{F}_{\mathrm{M}}$, that represents the maximum quantum yield of primary photochemistry, which expresses the probability that an absorbed photon be trapped by the PSII reaction center;

(ii) $\mathrm{PI}_{\mathrm{TOT}}$, performance index (potential) for energy conservation from photons absorbed by PSII to the reduction of PSI end acceptors.

On the same subsample of 15 leaves, chlorophyll content ( $\mathrm{Ch} \mathrm{l}_{\mathrm{SPAD}}$ ) was also measured by means of a portable chlorophyll meter (SPAD502DL Plus, Minolta; Spectrum Technologies Ltd., Plainfield, IL, USA). For each leaf, five measurements were taken and the average calculated. Values are reported in arbitrary units. 


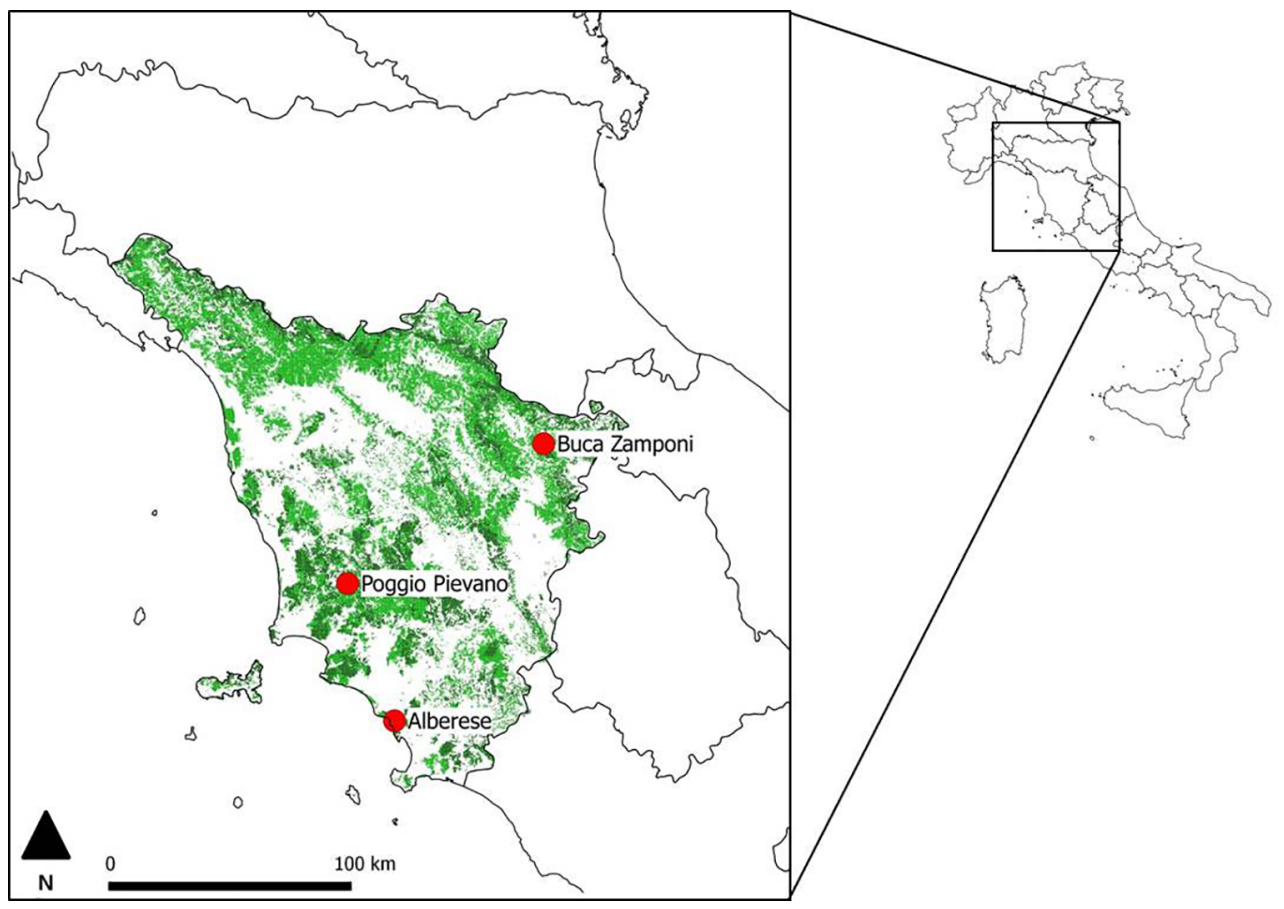

Fig. 1. Study sites in Tuscany (west-central Italy). On the right, map of Italy with the position of the Tuscany region; on the left, Tuscany with the three study sites (red points: beech in Buca Zamponi; Turkey oak in Poggio Pievano; holm oak in Alberese) and the forest vegetation cover: areas covered by beech, Turkey oak and olm oak woods are marked in dark green; other woods are shown in light green. Shapefile for forest vegetation were produced by Regione Toscana and downloaded by https:// www502.regione.toscana.it/geoscopio/ download/tematici/vegetazione_forestale/ index.html (retrieved at 12/6/2019).

Table 1

Study sites, dominant tree species, number of $800 \mathrm{~m}^{2}$ plots, stand characteristics (tree age, height, and density), and number, stem diameter and defoliation of assessed trees (mean $\pm \mathrm{sd}$ ).

\begin{tabular}{llll}
\hline Site & Buca Zamponi & Poggio Pievano & Alberese \\
\hline Dominant species & Fagus sylvatica & Quercus cerris & Quercus ilex \\
Plots, n & 5 & 4 & 3 \\
Age in 2016, y & 71 & $22-57$ & 85 \\
Height, m & $24.1 \pm 2.7$ & $13.0 \pm 4.7$ & $15.3 \pm 5.6$ \\
Density, n ha & $698 \pm 677$ & $3232 \pm 2094$ & $1717 \pm 2086$ \\
Assessed trees, n & 19 & 14 & 11 \\
Assessed trees, DBH, cm & $32.0 \pm 12.0$ & $16.9 \pm 6.6$ & $27.6 \pm 13.0$ \\
Assessed trees, & $28 \pm 20$ & $19 \pm 14$ & $29 \pm 23$ \\
$\quad$ defoliation, \% & $(\min : 0 \% ; \max :$ & $(\min : 0 \%$; max: & (min: $5 \%$; max: \\
& $65 \%)$ & $40 \%)$ & $75 \%)$ \\
\hline
\end{tabular}

\subsubsection{Leaf morphology}

The following morphological variables were subsequently measured on the subsample of 15 leaves:

Leaf thickness (LT; mm); three measurements were taken between the border and the midrib of each leaf, avoiding larger veins, using a digital caliper (Baxlo ${ }^{\circledR}$ mod. 3000DIG), and the average was calculated;

Leaf area (LA; $\mathrm{mm}^{2}$ ), lamina length ( $\left.\mathrm{LaL} ; \mathrm{mm}\right)$, lamina width (LaW; $\mathrm{mm})$, left $(\mathrm{WL} ; \mathrm{mm})$ and right (WR; mm) part of the lamina width; leaves were first scanned and images were then analyzed using the free software Image J (Schneider et al. 2012);

Fluctuating asymmetry (FA) was calculated as follows (Graham et al. 2010):

$F A=2 \frac{|W L-W R|}{W L+W R}$

Dry weight (DW; mg): 100 leaves per tree were dried at $60{ }^{\circ} \mathrm{C}$ to a constant weight (for $72 \mathrm{~h}$ ) to determine the dry mass and to calculate the average dry weight per leaf;

Specific leaf area (SLA = LA/DW; $\mathrm{mm}^{2} / \mathrm{mg}$ ) and leaf volume $\left(\mathrm{LV}=\mathrm{LAxLT} ; \mathrm{mm}^{3}\right)$ were also calculated .

\subsubsection{Stable isotope ratios}

For the stable isotope ratio analysis of $\mathrm{C}$ and $\mathrm{N}\left({ }^{13} \mathrm{C} /{ }^{12} \mathrm{C}\right.$ expressed as $\delta^{13} \mathrm{C},{ }^{15} \mathrm{~N} /{ }^{14} \mathrm{~N}$ expressed as $\delta^{15} \mathrm{~N}$ ), the subsamples of 100 leaves per tree, previously dried for the DW calculation, were pulverized by a cryogenic grinding machine (CryoMill, Retsch). To determine $\delta^{13} \mathrm{C}$ and $\delta^{15} \mathrm{~N}$, an aliquot of the samples (two replicates per tree, $3.0 \pm 0.05 \mathrm{mg}$ each) was transferred into tin capsules and then combusted in an Elementar Analyser (Vario EL III Elementar Analysensysteme GmbH, Hanau, Germany), which was connected to the isotope ratio mass spectrometer (Isoprime, Manchester, UK), according to the procedure described in Gori et al. (2014). The isotope composition of the leaves was reported in the standard delta notation ( $\delta$ in \%o) against the Vienna Pee Dee Belemnite (V-PDB) international standard for $\delta^{13} \mathrm{C}$ and atmospheric $\mathrm{N}_{2}$ for $\delta^{15} \mathrm{~N}$ as follows:

$\delta(\%)=\frac{\text { Rsample }}{\text { Rstandard }}-1$

where Rsample and Rstandard are the ${ }^{13} \mathrm{C} /{ }^{12} \mathrm{C},{ }^{15} \mathrm{~N} /{ }^{14} \mathrm{~N}$ ratios of the samples and of the standards, respectively. The relative precision of the repeated analysis was $<0.3 \%$ for $\delta^{13} \mathrm{C}$ and $\delta^{15} \mathrm{~N}$.

The N\% and $\mathrm{C} \%$ of the samples were analyzed by comparing the area of the peaks of the samples with that of the peak of the 'atropine' working standard, with a known content in $\mathrm{C}$ and $\mathrm{N}$. This made it possible to calculate the carbon-nitrogen ratio $(\mathrm{C}: \mathrm{N})$.

\subsection{Data analysis}

The coefficient of variation (CV, \%) of leaf traits was calculated for the 15-leaf subsamples of each tree, for each of the three species. Data were analyzed at tree level by non-parametric statistics to test the correlations between crown defoliation and leaf traits (Kendall Tau test) and to test the differences between undefoliated (i.e., defoliation $\leq 25 \%$ ) and defoliated (i.e., defoliation $>25 \%$ ) trees (Mann-Whitney $U$ test). Statistical analyses were carried out using the Dell ${ }^{\mathrm{TM}}$ Statistica ${ }^{\mathrm{TM}}$ 13.1 (Tibco software Inc.) software. Since the purpose of the study was to test the relationship between defoliation and functional leaf traits, analyses were carried out within each species without distinguishing among plots. We expect that - given the overall balance in sampling 

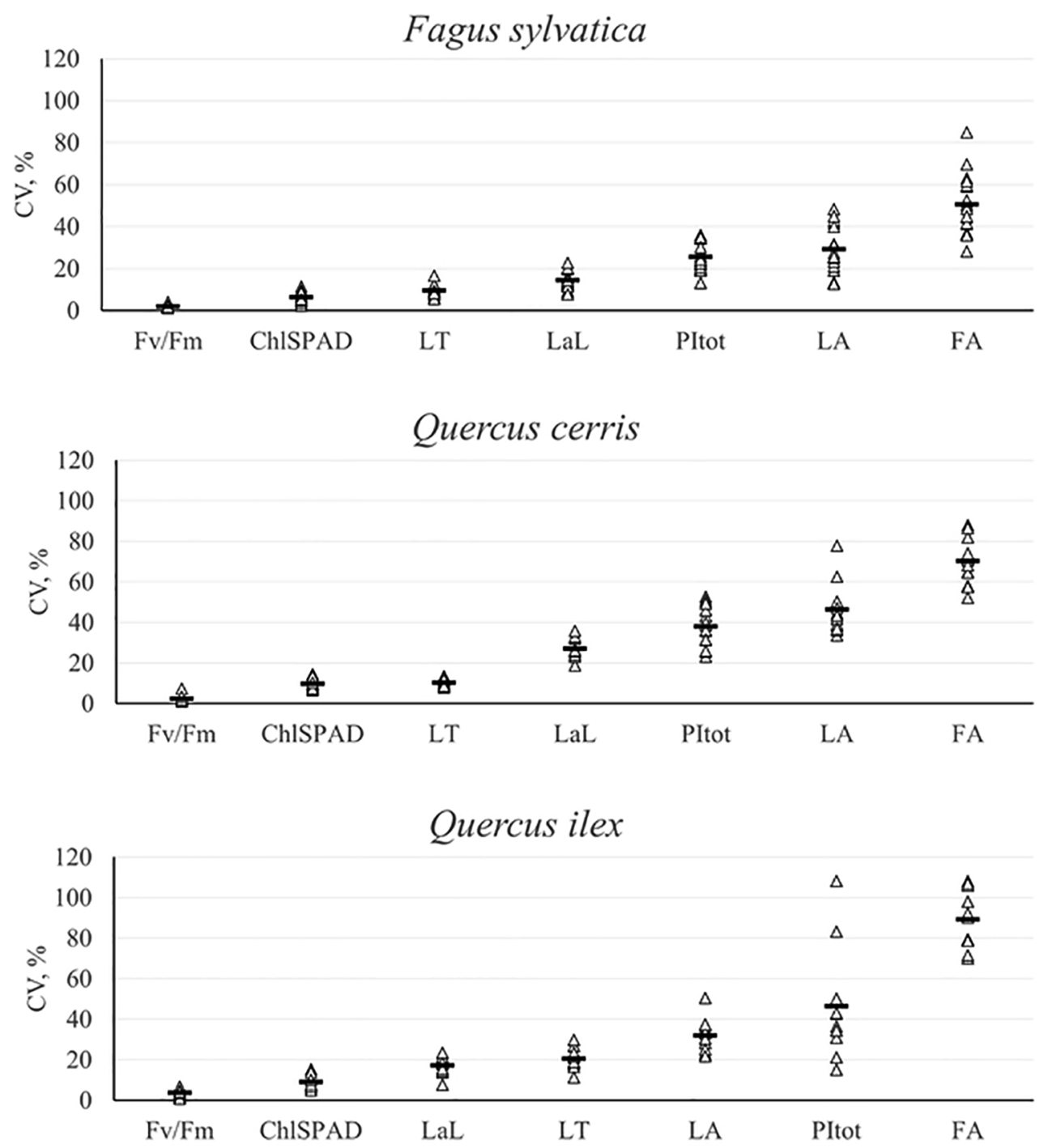

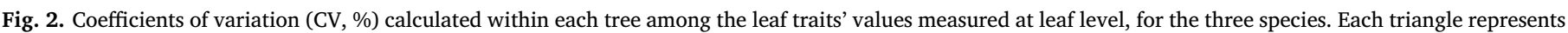
a tree; bars represent the mean value among trees for each leaf trait.

within each plot (see above) - the effect of variability among plots would have not caused any bias.

\section{Results}

\subsection{Within-tree variability}

Fig. 2 shows the within-individuals variability (CV, \%) calculated for each leaf trait measured at leaf level. Despite the fact that leaves were collected from the upper sun-exposed part of the crown of each tree to control variability, for some leaf traits the $\mathrm{CV} \%$ was quite high. $\mathrm{F}_{\mathrm{V}} / \mathrm{F}_{\mathrm{M}}$ and chlorophyll content showed a very low and steady variability (e.g. CV < 20\%), while FA displayed the largest variability for all three species, ranging on average from $51 \%$ to $89 \%$. LA and $\mathrm{PI}_{\mathrm{TOT}}$ variability was also quite high, with mean values between $25 \%$ and $46 \%$.

\subsection{Individual tree defoliation $v$ s. multiple health and functional indicators}

Table 2 shows the coefficients of correlation (Kendall Tau) between defoliation and a set of tree health indicators and functional leaf traits. In European beech trees, defoliation showed a significant positive correlation $(\mathrm{p}<0.05)$ with damage to individual trees (number of agents, number of affected parts, extent on leaves and branches) and with the frequency of leaves with high damage extent (DLS > 50). Defoliation was negatively correlated with dry weight (DW), carbon/ nitrogen ratio (C:N), leaf volume (LV) and photosynthetic efficiency $\left(\mathrm{F}_{\mathrm{V}} / \mathrm{F}_{\mathrm{M}}\right)$.

In Turkey oak, tree defoliation showed a significant positive correlation with tree damage, in terms of number of affected parts and extent on branches.

Also for holm oak trees, the damage extent on branches was significantly correlated to defoliation. A significant positive correlation was evidenced between defoliation and leaf area (LA).

\subsection{Defoliated $v$ s. undefoliated trees}

Table 3 shows the mean values of the considered leaf traits for European beech in two defoliation classes (undefoliated, $\leq 25 \%$ and defoliated, $>25 \%$ ), and the output of Mann-Whitney U Test carried out between undefoliated and defoliated trees.

As expected from previous correlation results, defoliated European beech trees showed a significantly $(\mathrm{p}<0.001)$ larger amount of damaged leaves, of leaves with high extent of damaged surface (DLS > 50), and a significantly lower photosynthetic efficiency $\left(\mathrm{F}_{\mathrm{V}} /\right.$ $\mathrm{F}_{\mathrm{M}}$ ) in comparison to undefoliated trees. Leaf damage was mostly 
Table 2

Kendall Tau correlation coefficients between tree defoliation and damage and leaf traits for the three species. Significant correlations are evidenced in bold and with one $(\mathrm{p}<0.05)$ or two $(\mathrm{p}<0.001)$ asterisks.

\begin{tabular}{|c|c|c|c|}
\hline Variable & $\begin{array}{l}\text { Fagus sylvatica } \\
\mathrm{n}=19\end{array}$ & $\begin{array}{l}\text { Quercus cerris } \\
\mathrm{n}=14\end{array}$ & $\begin{array}{l}\text { Quercus ilex } \\
\mathrm{n}=11\end{array}$ \\
\hline \multicolumn{4}{|l|}{ Measured at tree level } \\
\hline Causal agents & $0.417^{*}$ & 0.268 & 0.236 \\
\hline Affected parts of tree & $0.349^{*}$ & $0.420^{*}$ & 0.133 \\
\hline Damage extent on leaves & $0.650 * *$ & -0.078 & -0.432 \\
\hline Damage extent on branches & $0.385^{*}$ & $0.602 *$ & $0.690 *$ \\
\hline Damage extent on stem & 0.094 & n.a. & 0.191 \\
\hline DLS $>50$ & $0.520^{*}$ & 0.239 & 0.404 \\
\hline DW & $-0.353^{*}$ & -0.034 & 0.374 \\
\hline SLA & 0.084 & 0.125 & 0.224 \\
\hline$\delta^{13} \mathrm{C}$ & 0.048 & 0.239 & -0.112 \\
\hline$\delta^{15} \mathrm{~N}$ & -0.036 & 0.034 & -0.075 \\
\hline $\mathrm{C}: \mathrm{N}$ & $-0.394^{*}$ & 0.125 & -0.187 \\
\hline \multicolumn{4}{|l|}{ Measured at leaf level } \\
\hline LT & -0.048 & -0.046 & -0.299 \\
\hline LaL & -0.287 & -0.193 & 0.150 \\
\hline LA & -0.251 & 0.148 & $0.524 *$ \\
\hline LV & $-0.358^{*}$ & -0.011 & 0.262 \\
\hline FA & 0.108 & 0.262 & 0.150 \\
\hline $\mathrm{F}_{\mathrm{V}} / \mathrm{F}_{\mathrm{M}}$ & $-0.370^{*}$ & 0.034 & 0.075 \\
\hline $\mathrm{PI}_{\mathrm{TOT}}$ & -0.299 & 0.125 & 0.000 \\
\hline $\mathrm{Chl}_{\mathrm{SPAD}}$ & 0.119 & -0.034 & -0.075 \\
\hline
\end{tabular}

attributable to insects (present on $100 \%$ of trees) and fungi (present on $89 \%$ of defoliated trees) (Table 6). The effects of late frost - occurred in April 2016 (Bascietto et al. 2019) - were detected on $22 \%$ of defoliated trees (10\% on undefoliated ones). Damage on branches was observed mostly on defoliated trees (44\%), but its causes were not identified. A minority of trees showed stems affected by fungi, with no substantial differences between defoliated (11\%) and undefoliated (10\%) trees.

For Turkey oak, defoliated trees had a significantly $(\mathrm{p}<0.05)$ larger extent of damage on branches ( $10 \%$ vs. $2.2 \%$ of undefoliated trees) (Table 4) caused by unidentified factors (Table 6). In addition, the presence of Hedera helix L. was detected on the stem on $40 \%$ of defoliated Turkey oak trees (data not shown). Damage on leaves due to insects affected both undefoliated (56\%) and defoliated (60\%) trees (Table 6).

Defoliated holm oak trees also displayed a significantly $(\mathrm{p}<0.001)$ larger extent of damage on branches ( $20 \%$ vs. $3 \%$ of undefoliated trees) (Table 5) whose causal agent was not identified. Such a damage was found on all defoliated trees and on $50 \%$ of undefoliated ones (Table 6). Damage on stem was caused by fungi, present on $60 \%$ of defoliated trees. Insects also caused damage on holm oak, with slight differences between undefoliated (17\%) and defoliated (20\%) trees (Table 6). Stems of undefoliated Turkey oak and holm oak were never affected by any agent (Table 6).

\section{Discussion}

There are several indicators to measure tree vitality (Dobbertin, 2005). However, the importance of selecting and adopting appropriate cost-effective field methods should be recognized, and this is particularly true in case of large-scale, long-term forest monitoring. The set of indicators tested in this study was selected according to the literature (Bussotti and Pollastrini 2015, 2017; Innes, 1993; Kalaji et al., 2016; Niinemets, 2010; Nikiforou and Manetas, 2017; Pollastrini et al., 2016; Weiher et al., 1999) and with the aim to test the effectiveness of additional indicators to complement the information provided by already well-established indicators of tree health and vitality.

Defoliation is one of the five indicators considered under Criterion 2 (Forest Health and Vitality) by Forest Europe (FOREST EUROPE, 2015), and defoliation data are obtained by the ICP Forests (International Cooperative Programme on Assessment and Monitoring of Air Pollution Effects on Forests; http://icp-forests.net/). As any indicator, defoliation has advantages (low cost, ease of application, available long-term, large-scale data series) and disadvantages (observer error, uncertain relationship with actual forest and tree health). We adopted a multiproxy approach to evaluate tree health of three common broadleaved species in Italy, combining defoliation and other consolidated indicators based on the visual assessment of crown condition (Eichhorn et al., 2016), and measuring functional leaf traits (Bussotti and Pollastrini, 2015).

Table 3

Mean values ( \pm standard deviation, sd) of Fagus sylvatica tree condition and leaf traits measured at tree and leaf level for the two defoliation classes, and MannWhitney U Test ( $\mathrm{Z}$ value) results obtained comparing undamaged (i.e., defoliation $\leq 25 \%$ ) and damaged (i.e., defoliation $>25 \%$ ) trees. Significant differences between the two defoliation classes are evidenced in bold and with one $(\mathrm{p}<0.05)$ or two $(\mathrm{p}<0.001)$ asterisks.

\begin{tabular}{|c|c|c|c|c|c|}
\hline \multirow{2}{*}{$\begin{array}{l}\text { Variable } \\
\text { Measured at tree level }\end{array}$} & \multicolumn{2}{|c|}{ Defoliation $\leq 25 \%(n=10)$} & \multicolumn{2}{|c|}{$\begin{array}{l}\text { Defoliation }>25 \% \\
(\mathrm{n}=9)\end{array}$} & \multirow{2}{*}{$\begin{array}{l}\text { Mann-Whitney } U \text { test } \\
\text { Z adjusted }\end{array}$} \\
\hline & mean & sd & mean & sd & \\
\hline Defoliation, \% & 13.0 & 8.56 & 45.6 & 12.61 & $-3.646^{* *}$ \\
\hline Causal agents, $\mathrm{n}$ & 2.1 & 0.57 & 2.7 & 1.00 & -1.336 \\
\hline Affected parts of the tree, $n$ & 1.2 & 0.63 & 1.6 & 0.73 & -1.1427 \\
\hline Damage extent on leaves, $\%$ & 22.0 & 12.74 & 47.8 & 12.53 & $-3.078^{*}$ \\
\hline Damage extent on branches, \% & 0.5 & 1.58 & 3.3 & 4.33 & -1.692 \\
\hline Damage extent on stem, \% & 0.5 & 1.58 & 0.6 & 1.67 & 0.000 \\
\hline DLS $>50, \%$ & 10.5 & 14.23 & 48.2 & 29.52 & $-2.823^{*}$ \\
\hline $\mathrm{DW}, \mathrm{mg}$ & 105.1 & 32.95 & 83.3 & 20.47 & 1.307 \\
\hline SLA, $\mathrm{mm}^{2} \mathrm{mg}^{-1}$ & 14.6 & 5.71 & 14.3 & 3.38 & -0.204 \\
\hline$\delta^{13} \mathrm{C}, \%$ & -28.6 & 0.71 & -28.5 & 1.21 & -0.694 \\
\hline$\delta^{15} \mathrm{~N}, \%$ & -3.9 & 0.54 & -3.9 & 0.36 & -0.204 \\
\hline $\mathrm{C}: \mathrm{N}$ & 23.5 & 2.01 & 22.3 & 1.34 & 1.266 \\
\hline \multicolumn{6}{|l|}{ Measured at leaf level } \\
\hline $\mathrm{LT}, \mathrm{mm}$ & 0.30 & 0.038 & 0.31 & 0.044 & -0.367 \\
\hline $\mathrm{LaL}, \mathrm{mm}$ & 54.6 & 5.83 & 98.0 & 7.33 & 1.674 \\
\hline $\mathrm{LA}, \mathrm{mm}^{2}$ & 1418 & 293.6 & 1176 & 341.1 & 1.429 \\
\hline $\mathrm{LV}, \mathrm{mm}^{3}$ & 424 & 78.5 & 354 & 84.9 & 1.347 \\
\hline $\mathrm{FA}$ & 0.15 & 0.026 & 0.17 & 0.033 & -1.347 \\
\hline $\mathrm{F}_{\mathrm{V}} / \mathrm{F}_{\mathrm{M}}$ & 0.83 & 0.011 & 0.82 & 0.015 & $2.164 *$ \\
\hline $\mathrm{PI}_{\mathrm{TOT}}$ & 1.17 & 0.292 & 1.08 & 0.327 & 0.776 \\
\hline $\mathrm{Chl}_{\mathrm{SPAD}}$ & 36.0 & 2.39 & 36.5 & 1.89 & -0.612 \\
\hline
\end{tabular}


Table 4

Mean values ( \pm standard deviation, sd) of Quercus cerris tree condition and leaf traits measured at tree and leaf level for the two defoliation classes, and MannWhitney U Test ( $\mathrm{Z}$ value) results obtained comparing undamaged (i.e., defoliation $\leq 25 \%$ ) and damaged (i.e., defoliation $>25 \%$ ) trees. Significant differences $(\mathrm{p}<0.05)$ between the two defoliation classes are evidenced in bold and with one asterisk.

\begin{tabular}{|c|c|c|c|c|c|}
\hline \multirow{2}{*}{$\begin{array}{l}\text { Variable } \\
\text { Measured at tree level }\end{array}$} & \multicolumn{2}{|c|}{ Defoliation $\leq 25 \%(\mathrm{n}=9)$} & \multicolumn{2}{|c|}{$\begin{array}{l}\text { Defoliation > } 25 \% \\
(n=5)\end{array}$} & \multirow{2}{*}{$\begin{array}{l}\text { Mann-Whitney } U \text { test } \\
\text { Z adjusted }\end{array}$} \\
\hline & mean & sd & mean & sd & \\
\hline Defoliation, \% & 11.1 & 9.61 & 34.0 & 4.18 & $-2.953^{*}$ \\
\hline Causal agents, $\mathrm{n}$ & 1.2 & 0.97 & 2.0 & 0.71 & -1.338 \\
\hline Affected part of the tree, $n$ & 1.1 & 0.93 & 2.0 & 0.71 & -1.582 \\
\hline Damage extent on leaves, $\%$ & 5.6 & 5.27 & 11.0 & 19.17 & 0.140 \\
\hline Damage extent on branches, \% & 2.2 & 2.64 & 10.0 & 8.66 & $-2.337^{*}$ \\
\hline Damage extent on stem, $\%$ & 0.0 & 0.00 & n.a. & 0.00 & - \\
\hline DLS $>50, \%$ & 6.0 & 3.22 & 6.4 & 3.63 & -0.267 \\
\hline $\mathrm{DW}, \mathrm{mg}$ & 112.7 & 20.92 & 129.1 & 45.42 & -0.133 \\
\hline SLA, $\mathrm{mm}^{2} \mathrm{mg}^{-1}$ & 10.7 & 2.27 & 10.6 & 2.13 & 0.000 \\
\hline$\delta^{13} \mathrm{C}, \%$ & -28.4 & 0.65 & -28.1 & 0.94 & -1.200 \\
\hline$\delta^{15} \mathrm{~N}, \%$ & -5.5 & 0.64 & -5.8 & 0.86 & 0.533 \\
\hline $\mathrm{C}: \mathrm{N}$ & 25.9 & 1.39 & 26.1 & 1.12 & -0.533 \\
\hline \multicolumn{6}{|l|}{ Measured at leaf level } \\
\hline $\mathrm{LT}, \mathrm{mm}$ & 0.41 & 0.023 & 0.40 & 0.038 & 0.267 \\
\hline $\mathrm{LaL}, \mathrm{mm}$ & 66.5 & 5.33 & 67.3 & 12.98 & 0.667 \\
\hline $\mathrm{LA}, \mathrm{mm}^{2}$ & 1191 & 251.3 & 1312 & 328.4 & -0.800 \\
\hline $\mathrm{LV}, \mathrm{mm}^{3}$ & 483 & 86.3 & 537 & 152.6 & -0.133 \\
\hline $\mathrm{FA}$ & 0.22 & 0.055 & 0.22 & 0.068 & 0.000 \\
\hline $\mathrm{F}_{\mathrm{V}} / \mathrm{F}_{\mathrm{M}}$ & 0.83 & 0.009 & 0.83 & 0.008 & 0.000 \\
\hline $\mathrm{PI}_{\mathrm{TOT}}$ & 1.57 & 0.413 & 1.63 & 0.236 & -0.400 \\
\hline $\mathrm{Chl}_{\mathrm{SPAD}}$ & 41.0 & 3.36 & 39.6 & 2.11 & 0.667 \\
\hline
\end{tabular}

Our results can be discussed according to both a methodological and an operational perspective.

With regard to the former, methodological considerations arisen from our field study concern the sample size. Even if a certain withinindividual variability is supposed to exist (Albert et al., 2011), some leaf traits (i.e. FA, $\mathrm{LA}$ and $\mathrm{PI}_{\mathrm{TOT}}$ ) showed a high within-individual dispersion (i.e., $\mathrm{CV} \geq 25 \%$ ) in all the three species, despite the fact that the samples of 15 leaves per tree were collected from the external upper sun-exposed part of the crown, likely minimizing the intrinsic variability that exists between the different parts of the crown (Bussotti and Pollastrini, 2015; Petruzzellis et al., 2017). We expected our sample size (15 leaves per tree) to be large enough, as both a previous study
(Ferretti et al., 2016a) and the literature (e.g. Perez-Harguindeguy et al. (2013) recommend a minimum of five leaves from five individuals for SLA). FA showed the highest within-plant variability in all the three species (interspecific mean CV: 70\%); this high variability has already been observed on birch by Sandner et al. (2019), also applying different measurement approaches (i.e. landmark- and traditional distance-based FA measures); in addition, Kozlov et al. (2017) recognize the low reproducibility of the FA measurements. The high variability detected for LA could also affect SLA values (calculated as LA/DW ratio). This leaf trait (or its reciprocal leaf mass area, LMA $=1 /$ SLA) is largely used in studies on the adaptive capacity of trees to climate change (Aubin et al., 2016), on the plants' response to elevation (Midolo et al., 2019) and,

Table 5

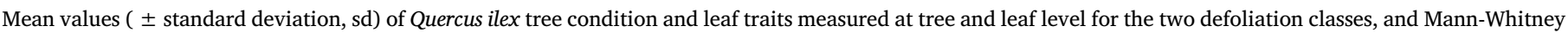

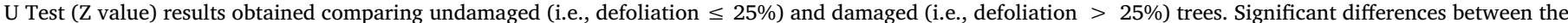
two defoliation classes are evidenced in bold and with one $(\mathrm{p}<0.05)$ or two $(\mathrm{p}<0.001)$ asterisks.

\begin{tabular}{|c|c|c|c|c|c|}
\hline \multirow{2}{*}{$\begin{array}{l}\text { Variable } \\
\text { Measured at tree level }\end{array}$} & \multicolumn{2}{|c|}{ Defoliation $\leq 25 \%(n=6)$} & \multicolumn{2}{|c|}{ Defoliation $>25 \%(n=5)$} & \multirow{2}{*}{$\begin{array}{l}\text { Mann-Whitney } U \text { test } \\
\mathrm{Z} \text { adjusted }\end{array}$} \\
\hline & mean & sd & mean & sd & \\
\hline Defoliation, \% & 12.5 & 7.58 & 49.0 & 18.17 & $-2.666^{* *}$ \\
\hline Causal agents, $\mathrm{n}$ & 1.2 & 0.41 & 1.6 & 0.55 & -1.309 \\
\hline Affected part of the tree, $\mathrm{n}$ & 1.7 & 0.82 & 2.0 & 1.00 & -0.489 \\
\hline Damage extent on leaves, \% & 12.0 & 7.58 & 5.0 & 8.66 & 1.519 \\
\hline Damage extent on branches, $\%$ & 3.0 & 2.74 & 20.0 & 28.06 & $-2.019 * *$ \\
\hline Damage extent on stem, \% & 1.0 & 2.24 & 4.0 & 5.48 & -0.775 \\
\hline DLS $>50, \%$ & 3.3 & 1.75 & 8.6 & 7.27 & -1.654 \\
\hline DW, mg & 65.2 & 8.79 & 83.5 & 28.28 & -1.552 \\
\hline SLA, $\mathrm{mm}^{2} \mathrm{mg}^{-1}$ & 6.5 & 1.15 & 7.1 & 0.58 & -0.822 \\
\hline$\delta^{13} \mathrm{C}, \%$ & -27.4 & 0.93 & -28.4 & 1.19 & 0.822 \\
\hline$\delta^{15} \mathrm{~N}, \% 0$ & -2.1 & 0.48 & -2.4 & 0.62 & 0.822 \\
\hline $\mathrm{C}: \mathrm{N}$ & 37.4 & 3.71 & 37.2 & 3.83 & 0.091 \\
\hline \multicolumn{6}{|l|}{ Measured at leaf level } \\
\hline $\mathrm{LT}, \mathrm{mm}$ & 0.54 & 0.095 & 0.50 & 0.065 & 0.639 \\
\hline $\mathrm{LaL}, \mathrm{mm}$ & 43.0 & 5.64 & 46.6 & 9.03 & -0.091 \\
\hline $\mathrm{LA}, \mathrm{mm}^{2}$ & 427 & 112.7 & 596 & 224.6 & -1.917 \\
\hline $\mathrm{LV}, \mathrm{mm}^{3}$ & 228 & 51.3 & 288 & 67.5 & -1.004 \\
\hline FA & 0.08 & 0.008 & 0.08 & 0.022 & -0.091 \\
\hline $\mathrm{F}_{\mathrm{V}} / \mathrm{F}_{\mathrm{M}}$ & 0.81 & 0.014 & 0.80 & 0.056 & -0.456 \\
\hline $\mathrm{PI}_{\mathrm{TOT}}$ & 1.45 & 0.216 & 1.49 & 0.405 & 0.091 \\
\hline $\mathrm{Chl}_{\text {SPAD }}$ & 45.8 & 2.50 & 44.6 & 1.86 & 1.004 \\
\hline
\end{tabular}


Table 6

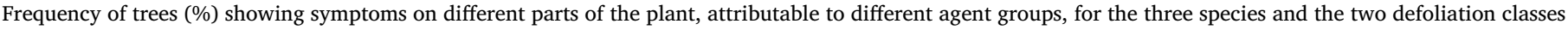
$(\leq 25 \%$ and $>25 \%)$.

\begin{tabular}{|c|c|c|c|c|c|c|c|}
\hline \multirow[t]{2}{*}{ Agent group } & \multirow[b]{2}{*}{ Affected part of the tree } & \multicolumn{2}{|c|}{ Fagus sylvatica } & \multicolumn{2}{|c|}{ Quercus cerris } & \multicolumn{2}{|c|}{ Quercus ilex } \\
\hline & & $\begin{array}{l}\leq 25 \\
(n=10)\end{array}$ & $\begin{array}{l}>25 \\
(n=9)\end{array}$ & $\begin{array}{l}\leq 25 \\
(n=9)\end{array}$ & $\begin{array}{c}>25 \\
(n=5)\end{array}$ & $\begin{array}{l}\leq 25 \\
(n=6)\end{array}$ & $\begin{array}{l}>25 \\
(n=5)\end{array}$ \\
\hline \multirow[t]{3}{*}{ Insects } & leaves & 100 & 100 & 56 & 60 & 17 & 20 \\
\hline & branches & 0 & 0 & 0 & 0 & 0 & 0 \\
\hline & stem & 0 & 0 & 0 & 0 & 0 & 0 \\
\hline \multirow[t]{3}{*}{ Fungi } & leaves & 80 & 89 & 0 & 0 & 0 & 0 \\
\hline & branches & 0 & 0 & 0 & 0 & 0 & 0 \\
\hline & stem & 10 & 11 & 0 & 0 & 0 & 60 \\
\hline \multirow[t]{3}{*}{ Unidentified } & leaves & 0 & 0 & 44 & 20 & 50 & 40 \\
\hline & branches & 10 & 44 & 44 & 100 & 50 & 100 \\
\hline & stem & 0 & 0 & 0 & 0 & 0 & 0 \\
\hline \multirow[t]{3}{*}{ Abiotic factors (late frost) } & leaves & 10 & 22 & 0 & 0 & 0 & 0 \\
\hline & branches & 0 & 0 & 0 & 0 & 0 & 0 \\
\hline & stem & 0 & 0 & 0 & 0 & 0 & 0 \\
\hline
\end{tabular}

more in general, in plant ecology (Moles, 2018).

PIs are calculated by complex formulae that incorporate several variables; the variability of such values was already documented in previous studies (Pollastrini et al., 2014). Thus, attention should be paid to sample size for these leaf traits displaying a large variability, and conclusions on plant response to stress based on their values should be approached cautiously, at least for the trees / species investigated in this study.

From an operational point of view, within the population of trees examined in our study we detected significant and common relationships between defoliation and symptoms of damage, either overall (cumulated number of damage symptoms on trees), on branches (all species) and foliage (European beech only). Although in many cases the causes of damage were not identified, the observed relationship between defoliation and tree damage confirmed the complementarity (and perhaps the link of causality) of these two indicators (see also Ferretti et al., 2014, 2018). It is worth noting that, although monitored at different levels (defoliation at tree level; forest damage at forest area level) both defoliation and forest damage are adopted under Forest Europe (2015), and connection / integration between these two indicators are worthwhile to be explored further. Most of our results, however, were species-specific. European beech provided the clearest signals: it was the only species for which defoliation was strongly related to the extent of damage on foliage, at crown (frequency of leaves affected) and leaf (amount of leaf part affected) level. A significant negative relationship existed between defoliation and leaf dry weight, leaf volume, and the maximum quantum yield of primary photochemistry $\left(\mathrm{F}_{\mathrm{V}} / \mathrm{F}_{\mathrm{M}}\right.$, significantly lower in defoliated trees). These results confirm the conclusions of previous studies on other forest tree species (Gottardini et al. 2016; Pollastrini et al. 2016). All these signals together point to a situation of reduced photosynthetic surface and reduced efficiency of the residual crown in defoliated trees, showing a reduction in tree vitality and potentially leading also to a reduction of growth (Dobbertin, 2005; Piper et al., 2015). Defoliated European beech trees showed also a reduced $\mathrm{C}: \mathrm{N}$ ratio, probably due to a decrease in the net carbon gain of trees by current photosynthesis, even if this is supposed to be a transient phenomenon (Palacio et al., 2012).

The lack of a clear relationship between defoliation and other indicators for Turkey oak and holm oak could be partially due to the smaller number of assessed trees and, in the case of holm oak, also to the narrow range of defoliation values explored ( $\max 40 \%$ ).

As for holm oak, its ability of resprouting after disturbances (e.g. drought) is well known (Barbeta and Penuelas, 2016). The presence of recently sprouted leaves, with a likely higher vitality, may have led to results decoupled from the degree of defoliation. Bussotti et al. (2003) also suggest that crown transparency (a widely used proxy for defoliation) of holm oak may be related to the crown architecture of individual trees.

\section{Conclusions}

International assessments and reporting of forest health and vitality have been largely based on tree defoliation. In this study we showed that defoliation of individual trees from three important European broadleaved species has a direct relationship with damage to different tree compartments. This may provide a possible link with another important indicator adopted by Forest Europe, namely indicator 2.4 "Forest Damage". This link can be worth of being explored further, e.g. by combining international data on damage and defoliation from individual trees (e.g. from ICP Forests) with data on damaged forest areas (provided by individual Countries under Indicator 2.4, Forest Europe, 2015). For European beech trees, the only species showing a direct connection between defoliation and damage to foliage, significant relationships were found also with a number of leaf traits related to photosynthetic efficiency.

We conclude that defoliation, although subject to a number of constraints, is an acceptable proxy indicator of trees and forest health, able to provide useful information on its status and trend. When species-specific differences are accounted for, the long-term defoliation data series can be seen as an important asset to further explore the changes in forest health across Europe over the past 30 years. The possibility of supplementing the tree crown condition assessment with more physiologically-relevant indicators (e.g. leaf traits) in intensive forest monitoring sites, for instance, will make it possible to build up a consolidated dataset for future evaluations. In such a case, however, considerable attention will be necessary to select the most appropriate trait(s) as well as the most appropriate sample size.

\section{CRediT authorship contribution statement}

E. Gottardini: Conceptualization, Formal analysis, Investigation, Visualization, Writing - original draft, Writing - review \& editing, Supervision. F. Cristofolini: Conceptualization, Investigation, Writing original draft, Writing - review \& editing. A. Cristofori: Conceptualization, Investigation, Visualization, Data curation, Writing original draft, Writing - review \& editing. M. Pollastrini: Investigation, Formal analysis, Writing - review \& editing. F. Camin: Investigation, Resources, Writing - review \& editing. M. Ferretti: Conceptualization, Methodology, Formal analysis, Investigation, Writing - original draft, Writing - review \& editing, Supervision. 


\section{Acknowledgements}

The Authors gratefully acknowledge the Forestry Research Centre (CREA, Arezzo - Italy) for the establishment and maintenance of the experimental trials in Tuscany (Italy), where all measurements were carried out. We are also grateful to Maria Cristina Viola for her help in leaf traits measurement, and TerraData environmetrics - Spin-off Company of the University of Siena (Italy) for crown condition assessment. We would like to thank the two anonymous reviewers for their detailed and constructive comments.

\section{Funding}

This work was supported by the LIFE Programme of the European Commission under the grant agreement LIFE14 ENV/IT/000514 (LIFE FutureForCoppices, "Shaping future forestry for sustainable coppices in Southern Europe: the legacy of past management trials").

\section{References}

Albert, C.H., Grassein, F., Schurr, F.M., Vieilledent, G., Violle, C., 2011. When and how should intraspecific variability be considered in trait-based plant ecology? Perspect. Plant Ecol. Evol. Systemat. 13 (3), 217-225.

Aubin, I., Munson, A.D., Cardou, F., Burton, P.J., Isabel, N., Pedlar, J.H., Paquette, A., Taylor, A.R., Delagrange, S., Kebli, H., Messier, C., Shipley, B., Valladares, F., Kattge, J., Boisvert-Marsh, L., McKenney, D., 2016. Traits to stay, traits to move: a review of functional traits to assess sensitivity and adaptive capacity of temperate and boreal trees to climate change. Environ. Rev. 24 (2), 164-186.

Barbeta, A., Penuelas, J., 2016. Sequence of plant responses to droughts of different timescales: lessons from holm oak (Quercus ilex) forests. Plant Ecolog. Divers. 9 (4), 321-338.

Bascietto, M., Bajocco, S., Ferrara, C., Alivernini, A., Santangelo, E., 2019. Estimating late spring frost-induced growth anomalies in European beech forests in Italy. Int. J. Biometeorol. 63 (8), 1039-1049.

Brumme, R., Khanna, P.K., 2009. Functioning and management of European beech ecosystems introduction. Function. Manage. Eur. Beech Ecosyst. 208, 1-4.

Bussotti, F., Borghini, F., Celesti, C., Leonzio, C., Cozzi, A., Bettini, D., Ferretti, M., 2003. Leaf shedding, crown condition and element return in two mixed holm oak forests in Tuscany, central Italy. For. Ecol. Manage. 176 (1-3), 273-285.

Bussotti, F., Cenni, E., Ferretti, M., Cozzi, A., Brogi, L., Mecci, A., 1995. Forest condition in Tuscany (Central Italy) - Field surveys 1987-1991. Forestry 68 (1), 11-24.

Bussotti, F., Gellini, R., Ferretti, M., Cenni, E., Pietrini, R., Sbrilli, G., 1992. Monitoring in 1989 of Mediterranean tree condition and nutritional status in Southern Tuscany, Italy. Forest Ecol. Manage. 51 (1-3), 81-93.

Bussotti, F., Pollastrini, M., 2015. Evaluation of leaf features in forest trees: methods, techniques, obtainable information and limits. Ecol. Ind. 52, 219-230.

Bussotti, F., Pollastrini, M., 2017. Traditional and novel indicators of climate change impacts on European forest trees. Forests 8 (4).

De Rigo, D., Caudullo, G., 2016. Quercus ilex in Europe: distribution, habitat, usage and threats. In: European Atlas of Forest Tree Species, San-Miguel-Ayanz, J., de Rigo, D., Caudullo, G., Houston Durrant, T., Mauri, A. (Eds.). Publ. Off. EU, Luxembourg.

De Rigo, D., Enescu, C.M., Houston Durrant, T., Caudullo, G., 2016. Quercus cerris in Europe: distribution, habitat, usage and threats. In: European Atlas of Forest Tree Species, San-Miguel-Ayanz, J., D. de Rigo, G. Caudullo, T. Houston Durrant, and A. Mauri (Eds.). Publ. Off. EU, Luxembourg.

Dobbertin, M., 2005. Tree growth as indicator of tree vitality and of tree reaction to environmental stress: a review. Eur. J. Forest Res. 124 (4), 319-333.

Eichhorn, J., P. Roskams, N. Potočić, V. Timmermann, M. Ferretti, V. Mues, A. Szepesi, D. Durrant, I. Seletković, H.W. Schröck, S. Nevalainen, F. Bussotti, P. Garcia, and S. Wulff. 2016. Part IV: Visual Assessment of Crown Condition and Damaging Agents. P. 54 in Manual on methods and criteria for harmonized sampling, assessment, monitoring and analysis of the effects of air pollution on forests. Thünen Institute of Forest Ecosystems, Eberswalde. Germany.

Ferretti, M., 1994. Mediterranean Forest Trees. A Guide for Crown Assessment, CEC-UN/ ECE, Brussels/Geneva.

Ferretti, M., 1997. Forest health assessment and monitoring - issues for consideration. Environ. Monit. Assess. 48 (1), 45-72.

Ferretti, M., 1998. Potential and limitation of visual indices of tree condition. Chemosphere 36 (4-5), 1031-1036.

Ferretti, M., Bacaro, G., Brunialti, G., Confalonieri, M., Cristofolini, F., Cristofori, A., Frati, L., Finco, A., Gerosa, G., Maccherini, S., Gottardini, E., 2018. Scarce evidence of ozone effect on recent health and productivity of alpine forests-a case study in Trentino, N, Italy. Environ. Sci. Pollut. Res. 25 (9), 8217-8232.

Ferretti, M., G. Bacaro, F. Cristofolini, A. Cristofori, S. Maccherini, and E. Gottardini. 2016a. Source of variability in Chlorophyll a fluorescence of Norway spruce (Picea abies (L.) H. Karst) trees: consequences for sampling. In: International Workshop on "Statistical inference for assessing and monitoring natural resources" http://hdl. handle.net/10449/36266, Siena, Italy.

Ferretti, M., Cutini, A., Gottardini, E., 2016b. Linee Guida per una preparazione coerente delle indagini e dei dati (V1 R0). Documento LIFE FutureForCoppiceS. P. 22.
Ferretti, M., Fischer, R., 2013. Forest Monitoring. Methods for Terrestrial Investigations in Europe with an Overview of North America and Asia. Elsevier, UK. 507 p.

Ferretti, M., Nicolas, M., Bacaro, G., Brunialti, G., Calderisi, M., Croise, L., Frati, L., Lanier, M., Maccherini, S., Santi, E., Ulrich, E., 2014. Plot-scale modelling to detect size, extent, and correlates of changes in tree defoliation in French high forests. For. Ecol. Manage. 311, 56-69.

FOREST EUROPE 2015. State of Europe's Forests 2015

Gea-Izquierdo, G., Ferriz, M., Garcia-Garrido, S., Aguin, O., Elvira-Recuenco, M., Hernandez-Escribano, L., Martin-Benito, D., Raposo, R., 2019. Synergistic abiotic and biotic stressors explain widespread decline of Pinus pinaster in a mixed forest. Sci. Total Environ. 685, 963-975.

Gori, Y., Camin, F., La Porta, N., Carrer, M., Battisti, A., 2014. Tree rings and stable isotopes reveal the tree-history prior to insect defoliation on Norway spruce (Picea abies (L.) Karst.). For. Ecol. Manage. 319, 99-106.

Gottardini, E., Cristofolini, F., Cristofori, A., Camin, F., Calderisi, M., Ferretti, M., 2016. Consistent response of crown transparency, shoot growth and leaf traits on Norway spruce (Picea abies (L.) H. Karst.) trees along an elevation gradient in northern Italy. Ecol. Ind. 60, 1041-1044.

Graham, J.H., Raz, S., Hel-Or, H., Nevo, E., 2010. Fluctuating asymmetry: methods, theory, and applications. Symmetry-Basel 2 (2), 466-540.

Iacopetti, G., Bussotti, F., Selvi, F., Maggino, F., Pollastrini, M., 2019. Forest ecological heterogeneity determines contrasting relationships between crown defoliation and tree diversity. For. Ecol. Manage. 448, 321-329.

IFNC. 2007. Inventario nazionale delle foreste e dei serbatoi forestali di carbonio (anno di riferimento 2005). [National Inventory of Forests and Forest Carbon stock (reference year 2005)]. Ministero delle Politiche Agricole, Alimentari e Forestali, Rome, Italy, [in Italian]. P. 653.

Innes, J.L., 1991. Forest condition and air-pollution in Great-Britain. Chem. Ind. (London) 3, 79-82.

Innes, J.L., 1993. Forest Health: Its Assessment and Status. CAB International, Wallingford, Oxon, UK.

Innes, J.L., 1998. Role of diagnostic studies in forest monitoring programmes. Chemosphere 36 (4-5), 1025-1030.

Kalaji, H.M., Jajoo, A., Oukarroum, A., Brestic, M., Zivcak, M., Samborska, I.A., Cetner, M.D., Lukasik, I., Goltsev, V., Ladle, R.J., 2016. Chlorophyll a fluorescence as a tool to monitor physiological status of plants under abiotic stress conditions. Acta Physiologiae Plantarum 38 (4).

Kozlov, M.V., Cornelissen, T., Gavrikov, D.E., Kunavin, M.A., Lama, A.D., Milligan, J.R. Zverev, V., Zvereva, E.L., 2017. Reproducibility of fluctuating asymmetry measurements in plants: sources of variation and implications for study design. Ecol. Ind. 73, 733-740.

Lorenz, M., W. Seidling, V. Mues, G. Becher, Fischer, R., 2001. Forest Condition in Europe. Results of the 2000 Large-scale Survey. In: 2001 Technical Report. Prepared by: Federal Research Centre for Forestry and Forest Products.

Midolo, G., De Frenne, P., Holzel, N., Wellstein, C., 2019. Global patterns of intraspecific leaf trait responses to elevation. Glob. Change Biol. 25 (7), 2485-2498.

Moles, A.T., 2018. Being John Harper: Using evolutionary ideas to improve understanding of global patterns in plant traits. J. Ecol. 106 (1), 1-18.

Mueller, E., Stierlin, H.R., 1990. Sanasilva. Tree crown photos, Swiss Federal Institute for Forest, Snow and Landscape Research, Birmensdorf, pp. 129.

Niinemets, U., 2010. Responses of forest trees to single and multiple environmental stresses from seedlings to mature plants: Past stress history, stress interactions, tolerance and acclimation. For. Ecol. Manage. 260, 1623-1639.

Nikiforou, C., Manetas, Y., 2017. Ecological stress memory: Evidence in two out of seven species through the examination of the relationship between leaf fluctuating asymmetry and photosynthesis. Ecol. Ind. 74, 530-534.

Palacio, S., Hernandez, R., Maestro-Martinez, M., Camarero, J.J., 2012. Fast replenishment of initial carbon stores after defoliation by the pine processionary moth and its relationship to the re-growth ability of trees. Trees-Struct. Funct. 26 (5), 1627-1640.

Perez-Harguindeguy, N., Diaz, S., Garnier, E., Lavorel, S., Poorter, H., Jaureguiberry, P., Bret-Harte, M.S., Cornwell, W.K., Craine, J.M., Gurvich, D.E., Urcelay, C., Veneklaas, E.J., Reich, P.B., Poorter, L., Wright, I.J., Ray, P., Enrico, L., Pausas, J.G., de Vos, A.C., Buchmann, N., Funes, G., Quetier, F., Hodgson, J.G., Thompson, K., Morgan, H.D., ter Steege, H., van der Heijden, M.G.A., Sack, L., Blonder, B., Poschlod, P., Vaieretti, M.V., Conti, G., Staver, A.C., Aquino, S., Cornelissen, J.H.C., 2013. New handbook for standardised measurement of plant functional traits worldwide. Aust. J. Bot. 61 (3), 167-234.

Petruzzellis, F., Palandrani, C., Savi, T., Alberti, R., Nardini, A., Bacaro, G., 2017. Sampling intraspecific variability in leaf functional traits: practical suggestions to maximize collected information. Ecol. Evol. 7 (24), 11236-11245.

Piper, F.I., Gundale, M.J., Fajardo, A., 2015. Extreme defoliation reduces tree growth but not C and N storage in a winter-deciduous species. Ann. Bot. 115 (7), 1093-1103.

Pollastrini, M., Feducci, M., Bonal, D., Fotelli, M., Gessler, A., Grossiord, C., Guyot, V., Jactel, H., Nguyen, D., Radoglou, K., Bussotti, F., 2016. Physiological significance of forest tree defoliation: results from a survey in a mixed forest in Tuscany (central Italy). For. Ecol. Manage. 361, 170-178.

Pollastrini, M., Holland, V., Bruggemann, W., Koricheva, J., Jussila, I., Scherer-Lorenzen, M., Berger, S., Bussotti, F., 2014. Interactions and competition processes among tree species in young experimental mixed forests, assessed with chlorophyll fluorescence and leaf morphology. Plant Biol. 16 (2), 323-331.

Potočić, N., Timmermann, V., Ognjenović, M., 2018. Tree crown condition in 2017. In: Michel, A., Seidling, W. and Prescher, A-K (Eds.). Forest Condition in Europe 2018. Technical Report of ICP Forests. Report under the UNECE Convention on Long-range Transboundary Air Pollution (Air Convention). BFW-Dokumentation 25/2018. Vienna: BFW Austrian Research Centre for Forests. 92 p. https://www.icp-forests. org/pdf/TR2018.pdf. 
Sandner, T.M., Zverev, V., Kozlov, M.V., 2019. Can the use of landmarks improve the suitability of fluctuating asymmetry in plant leaves as an indicator of stress? Ecol. Ind. 97, 457-465.

Schneider, C.A., Rasband, W.S., Eliceiri, K.W., 2012. NIH Image to ImageJ: 25 years of image analysis. Nat. Methods 9 (7), 671-675.

Seidling, W., 2019. Forest monitoring: Substantiating cause-effect relationships. Sci. Total Environ. 687, 610-617.

Solberg, S., 1999. Crown condition and growth relationships within stands of Picea abies. Scand. J. For. Res. 14 (4), 320-327.

Solberg, S., Tveite, B., 2000. Crown density and growth relationships between stands of Picea abies in Norway. Scand. J. For. Res. 15 (1), 87-96.
Strasser, R.J., Srivastava, A., Tsimilli-Michael, M. 2000. The fluorescence transient as a tool to characterize and screen photosynthetic samples. M. Yunus, U. Pathre, P. Mohanty (Eds.), Probing Photosynthesis: Mechanisms, Regulation and Adaptation, Taylor \& Francis, London, New York, p. 558.

Vacek, S., Hunova, I., Vacek, Z., Hejcmanova, P., Podrazsky, V., Kral, J., Putalova, T., Moser, W.K., 2015. Effects of air pollution and climatic factors on Norway spruce forests in the Orlick, hory Mts. (Czech Republic), 1979-2014. Eur. J. Forest Res. 134 (6), 1127-1142.

Weiher, E., van der Werf, A., Thompson, K., Roderick, M., Garnier, E., Eriksson, O., 1999. Challenging Theophrastus: A common core list of plant traits for functional ecology. J. Veg. Sci. 10 (5), 609-620. 